\title{
Antisystemic Movements, Yesterday and Today ${ }^{1}$
}

\author{
Immanuel Wallerstein \\ Yale University \\ immanuel.wallerstein@yale.edu
}

There have always been historical systems in which some relatively small group exploited the others. The exploited always fought back as best they could. The modern world-system, which came into existence in the long sixteenth century in the form of a capitalist world-economy, has been extremely effective in extracting surplus-value from the large majority of the populations within it. It did this by adding to the standard systemic features of hierarchy and exploitation the new characteristic of polarization.

The result has been an ever-increasing degree of exploitation by what we now call the $1 \%$ of the others (these days called the 99\%). Within the modern world-system, resistance initially took the form primarily of either spontaneous uprisings or escape into zones in which it was harder for the $1 \%$ to reach and impose its authority. However, the increasing mechanization and concentration of productive enterprises within the modern world-system led, as we know, to an ever-increasing degree of urbanization. The urbanization of the modern world-system in turn opened new ways for the working classes to challenge the modes of extraction by the dominant forces.

The French Revolution further changed the structure of the modern world-system by unleashing two new concepts, whose impact was to transform the modern world-system. These concepts were the "normality of change" as opposed to its exceptional and limited reality, and the "sovereignty of the people" as opposed to that of the ruler or the aristocracy. This pair of concepts was the basis of something new, a geoculture that spread throughout the historical system and legitimated radical "change" of the system by the "people." It was in response to this danger to the dominant forces that the three modern ideologies - conservatism, liberalism, and radicalismemerged.

Each of the ideologies represented a program of political action. Conservatism was the first and most immediate response, notably in the writings of Edmund Burke and Joseph de Maistre. The core of the conservative ideology was to deny the prudence, even the possibility, of substantial change. Conservatives reasserted the priority of the judgments of traditional elites, locally situated, and supported by religious institutions.

Liberalism arose as an alternative mode of containing the danger. Liberals argued that reactionary conservatism, which inevitably involved suppressive force, was self-defeating in the

\footnotetext{
${ }^{1}$ Keynote address delivered at the $38^{\text {th }}$ Annual Political Economy of the World-System conference, April 10, 2014, Pittsburgh, Pennsylvania.
}

Copyright $\bigcirc$ 2014, American Sociological Association, Volume 20, Number 2, Pages 158-172, ISSN 1076-156X 
medium run, pushing the oppressed to rebel openly. Instead, liberals said, elites should embrace the inevitability of some change and defer nominally to the sovereignty of the people, but insist that social transformation was a complicated and dangerous process that could only be done well and prudently by specialists whom all others should allow to make the crucial decisions. Liberals thus envisaged a slow, and limited, process of societal transformation.

Radicalism was the last ideology to emerge. It began as a small annex to liberalism. Radicals argued that relying on specialists would lead to no more than a slightly revised social structure. Instead, they said, the lower strata should pursue transformation of the system as rapidly as possible, guided by a democratic ethos and an egalitarian ideal.

The world-revolution of 1848 marked a turning-point in the relations of the three ideologies - rightwing conservatism, centrist liberalism, and leftwing radicalism. It began with a social uprising in Paris in February, in which the radical left seemed momentarily to seize state power. This uprising was unexpected by most persons - a happy surprise for the working classes, a serious danger from the point of view of the elites. It so frightened both conservatives and liberals that they buried their voluble differences that had loomed so large up to then and formed a political alliance to suppress the social revolution. The process in France essentially took three years, culminating in the creation of the Second Empire under Napoleon III.

Nor was the social revolution all that was happening. The same year, 1848, was the moment of nationalist uprisings in much of Europe - notably in Hungary, Poland, the Italies, and the Germanies. The historians have dubbed these uprisings "the springtime of the nations." Just like the social revolution in Paris, these various nationalist uprisings were suppressed within a few years - at least for the moment, but a long moment.

This pair of happenings in 1848 - social revolution in France and nationalist revolutions in many countries - forced a reconsideration of basic strategy by the tenants of each of the three ideologies. The conservatives noticed that the one major country in which nothing seemed to happen in 1848 was Great Britain. That seemed very curious since throughout the first half of the nineteenth century, radical forces had seemed to be the most extensive, active, and well-organized in Great Britain. Yet it was the one major country in which calm reigned amidst the pan-European storm of 1848.

What the conservatives then realized, and historians later confirmed, was that the British Tories had discovered a mode of containing radicalism far more effective than forceful suppression. The British Tories had been making constant concessions to the demands for social and institutional change. These concessions actually were relatively minor, but their repeated occurrence seemed to suffice to persuade the more radical forces that change was in fact taking place. After 1848, the British example persuaded conservatives elsewhere, especially in continental Europe, that perhaps they should revise their tactics. This revised analysis brought conservatives nearer to the position of the centrist liberals, and took the label of "enlightened conservatism."

Meanwhile, the radicals were equally unsettled by what happened. The principal tactics radicals had employed up to 1848 had been either spontaneous uprisings or utopian withdrawal. In 1848 radicals observed that their spontaneous uprisings were easily put down. And their utopian withdrawals turned out to be unsustainable. The lesson they drew was the necessity of replacing spontaneity with "organizing" the revolution - a program that involved more temporal patience as well as the creation of a bureaucratic structure. This shift of tactics brought radicals closer to the 


\section{Journal of World-Systems Research}

position of the centrist liberals, the radical bureaucrats now assuming the role of the specialists who would guide transformation.

Finally, the liberals too drew a major lesson from the world-revolution of 1848 . They began to emphasize their centrist position, as opposed to their previously primary role of confronting conservatives. They began to see the necessity of tactics that would pull both conservatives and radicals into their orbit, turning them into mere variants of centrist liberalism. In this effort, they turned out to be hugely successful for a very long time - indeed until the much later world-revolution of 1968.

It was in the second half of the nineteenth century that we see the organizational emergence of what we consider to be antisystemic movements. There were two main varieties-social movements and nationalist movements - as well as less strong varieties such as women's movements and ethno/racial/religious movements. These movements were all antisystemic in one simple sense: They were struggling against the established power structures in an effort to bring into existence a more democratic, more egalitarian historical system than the existing one.

These movements were however deeply divided in terms of their analysis of how to define the groups that were most oppressed, and what were the priorities of achieving the objectives of one kind of movement relative to other kinds of movements. These debates between the various movements have persisted right up to today.

One fundamental debate was how to think about the role of the states in the achievement of a different kind of historical system. There were those who argued that states were structures established by the elites of the system, mechanisms by which the elites controlled the others. States were therefore an enemy, to be shunned, and against which the movements must ceaselessly struggle. The principal tactic therefore must be to educate and transform the psychology of those who were oppressed, to turn them into permanent militants who would embody and transmit to others the values of a democratic, egalitarian world.

Against this view were arrayed those who agreed that the state was the instrument of the ruling elites, and for this very reason could not be ignored. Unless the movements seized power in the states, the ruling classes would use their strength - military and police strength, economic strength, and cultural strength - to crush the antisystemic movements. This group insisted that, precisely in order to transform the historical system, movements had first to achieve control of the state. We came to call this the "two-step strategy" - first obtain state power, then transform the world.

The second argument was between the social movements and the nationalist movements. The former insisted that the modern world-system was a capitalist system and that therefore the basic struggle was a class struggle within each country between the owners of capital (the "bourgeoisie") and those who had only their own labor power to sell (the "proletariat"). It was between these two groups that the democratic and egalitarian gulf was enormous and ever-increasing. It followed that the natural "historical actor" of transformation was the proletariat.

The nationalist movements assessed the world differently. They saw a world in which states were controlled either by an internal dominant ethnic group or by external forces. They argued that the most oppressed persons were the "peoples" who were denied their democratic rights and consequently were living in an ever-increasingly inegalitarian historical system. It followed that the natural "historical actors" were the oppressed nations. Only when these oppressed nations came to 
power in their own state could there be expectations of a more democratic, more egalitarian historical system.

These two splits - that between those who abjured state power versus those who sought to obtain it as the first step; and that between those who saw the proletariat versus those who saw the oppressed nations as the natural historical actors - were not the only matters under debate. Both the social movements and the nationalist movements insisted on the importance of "vertical" structures. That is, they both insisted that the road to success in obtaining state power was to have only one antisystemic structure in any state (actual state for the social movements, virtual state for the nationalist movements). They said that unless all other kind of antisystemic movements subordinated themselves to the single "principal" movement, the objective could not be achieved.

For example, take the women's or feminist movements. These movements insisted on the inegalitarian and undemocratic relationship of men and women throughout history and particularly in the modern world-system. They argued that the struggle against what was termed "patriarchy" was at least as important as any other struggle and was their primary concern as movements. Against this view, both the social and the nationalist movements argued that asserting an independent role for feminist movements weakened their cause, which took priority, and was "objectively" counterrevolutionary.

The "vertical" movements insisted that there could be women's auxiliaries of the social or of the nationalist movements, but that the realization of the feminist demands could only occur as a consequence of the realization of the demands of the "principal" historical actor (the proletariat or the oppressed nation). In effect, the vertical movements counseled deferral of the struggles of the feminist movements.

The same logic would be used against other kinds of movements - such as trade-union movements or movements of so-called "minorities" as socially-defined (whether by race, ethnicity, religion, or language). All these movements had to accept subordination to the principal movement and deferral of their demands. They could only be adjuncts of the principal movements, or else they were considered to be counter-revolutionary.

When these various movements first came to be large enough to be politically noticeable (circa the 1870s), the most important reality about all of them was that they were perhaps noticeable but in fact organizationally and politically quite weak. The idea that they could actually achieve state power seemed a matter of faith, unsustained by a sober assessment of the real rapport de forces in the modern world-system.

While their political power did increase slowly from then on, they still seemed relatively weak as late as 1945. It is therefore somewhat astonishing that in the period 1945-1970 the vertical antisystemic movements actually did achieve the first of the two steps. They did indeed come to state power, almost everywhere. This sudden shift in the political arena of the modern world-system warrants a careful explanation.

The end of the Second World War marked the onset of two important cyclical shifts in the history of the modern world-system. It marked both the beginning of a Kondratieff A-phase and the moment of undisputed hegemony in the world-system of the United States. The success of the antisystemic movements cannot be understood without placing it in this context. It is most revealing to start with U.S. hegemony, which can be considered a quasi-monopoly of geopolitical power. 


\section{Journal of World-Systems Research}

Hegemonic cycles are very long occurrences. But the high point, true hegemony, is actually rather brief. There have in fact only been three such high points in the history of the modern worldsystem - the United Provinces in the mid-seventeenth century, the United Kingdom in the midnineteenth century, and the United States in the mid-twentieth century. Each lasted perhaps for 25-50 years or so. The phase prior to the achievement of full hegemony has been each time a "thirty years' war" between a land-based power and a sea/air-based power. The "thirty years' war" in the most recent case was that between Germany and the United States from 1914-1945, and ended as we know, in the total defeat of Germany.

Hegemony is built on the existence of an enormous economic advantage, combined with political, cultural, and military strength. As of 1945, the United States was able to assemble all this to its advantage. In 1945, the United States was the only important industrial power in the entire world that had escaped major destruction of its plants. Indeed, on the contrary, wartime production had made their productive enterprises more extensive and efficient than ever. At this time U.S. production was so efficient that it could sell its leading products in other countries at prices lower than these countries could produce these products themselves, despite the costs involved in transportation. These U.S.-based quasi-monopolies were guaranteed by the active role of the state in protecting and enhancing their exclusive privileges.

The result was the largest (by far) expansion of the world production of surplus-value in the 500-year-long history of the modern world-system. While the United States was the principal beneficiary - its state, its enterprises, its residents - the worldwide rise in production produced benefits to most countries, if to a far lesser degree than to the United States.

The problem with quasi-monopolies in leading products is that they are self-liquidating over time, for several reasons. The first is that the high rate of capital accumulation made these quasimonopolies a very tempting target for penetration by other producers who sought to enter the world market. These other producers stole or bought technical knowledge and used their influence on other governments to counter the protectionist policies of the government primarily protecting the quasimonopolies.

Furthermore, the U.S. government actively aided west European and Japanese economic reconstruction in order to provide customers for U.S. production as well as to maintain the political loyalty of these de facto satellite regimes. In addition, as long as the quasi-monopolies were in effective operation, the leading enterprises feared most of all any stoppage of production, since stoppages involved irrecoverable losses. Hence it made short-term economic sense to make wage concessions to their workers rather than risk strikes. But of course over time this raised the cost of production and lessened the advantage vis-à-vis potential competitors.

By the 1960s, the improved economic position of western Europe and Japan could be observed in the dramatic inversion in one key leading industry, automobiles. Whereas in 1950 U.S. manufacturers could undersell competitors in their home markets, by the mid-1960s the reverse was true. West European and Japanese automobile producers began to penetrate the U.S. domestic market.

For all these reasons, others over time did in fact succeed in penetrating the world market, thereby increasing competition. This no doubt benefited some consumers, but at the same time it reduced the level of profitability of the erstwhile quasi-monopolies. U.S. producers had to give 
thought to how they could minimize the losses they were incurring in the rate of capital accumulation.

It was not helpful to U.S. capitalists that, as their quasi-monopoly of production was disappearing, so was the quasi-monopoly of U.S. geopolitical strength, which was beginning its inevitable decline. To understand how this happened, we have to see how it was established in the first place circa 1945 . We have already mentioned the superiority in productive efficiency and the fact that this advantage underlay its political and cultural dominance.

There was however one last element in securing full hegemony, which was the military sphere. The fact that prior to 1939, the United State had not invested heavily in military technology and manpower had been one of the key elements in enabling them to achieve productive dominance. The Second World War changed that allocation of state revenues. The United States developed atomic weapons and displayed their power by using them against Japan. However, sentiment within the United States was heavily in favor of reducing the size of the armed forces.

The problem for the United States was that a hegemonic power cannot abstain from military commitment. It comes with the position. And in 1945 there was one other power that had a very strong military, the U.S.S.R., and unlike the United States it showed no signs of rushing to dismantle it. It was clear that, if the United States was to exercise hegemony, it had to make some deal with the Soviet Union.

They did make such a deal, and we have dubbed it "Yalta." This refers not really to the actual decisions of this meeting in February 1945 of what were then called the Big Three-the United States, Great Britain, and the Soviet Union. "Yalta" was rather a set of unsigned tacit arrangements to which the United States and the Soviet Union were committed and which were maintained in place for quite some time.

There were in fact three such tacit arrangements. The first was that there would be a division of the world in terms of zones of influence and control. The line would be drawn more or less where the two armies ended up in 1945, a division in the middle of Germany going from north to south called the Oder-Neisse line, and the 38th Parallel in Korea. In effect, the Soviet Union would have primacy in about one-third of the globe and the United States in the other two-thirds. The deal was that neither side would try to change these frontiers by the use of military force.

The second part of the deal had to do with economic reconstruction. As we noted, U.S. producers needed customers. The Marshall Plan and similar arrangements with Japan provided these customers. The tacit U.S.-Soviet agreement was that the United States would provide such economic assistance to countries in its zone but not to any country in the Soviet zone, where the Soviet Union could arrange matters as it saw fit.

Finally, the third part of the deal was the so-called Cold War. The Cold War refers to the mutual denunciation of both sides, each proclaiming its virtues and its inevitable long-term ideological victory as well as the evil machinations of the other side. The deal was that this was not to be taken seriously, or rather that the function of the mutual denunciations was meant in no way to countermand the first part of the deal — the de facto freezing of frontiers indefinitely. The actual objective of Cold War rhetoric was not to transform the other side but to maintain the loyalty of the satellites on each side.

Although the first part of the deal lasted until the collapse of the Soviet Union, and the second part until at least the 1970s, the cozy arrangement began to be eroded by several factors. The 


\section{Journal of World-Systems Research}

de facto international status quo was not at all to the liking of a number of countries in what we then called the Third World. The first major dissident was the Chinese Communist Party (CCP), which straightforwardly rejected Stalin's advice to come to a power-sharing deal with the Kuomintang. Instead, the CCP's army entered Shanghai, and it proclaimed the People's Republic of China.

This dissidence was followed by the insistence of the Viet Minh to achieve control over all of Vietnam, the insistence of the Algerian Front de Libération Nationale to obtain total independence, and the insistence of the Cubans to arm themselves against U.S. intrusion. In each of these cases, it was the Third World power that was forcing the hand of the Soviet Union and not the other way around. On the other hand, the Soviet Union and the United States successfully sought to ensure that there was no use of nuclear weapons, which would have violated the pledge of mutual restraint.

The Vietnam War, in which the United States committed its troops actively, weakened U.S. hegemony in several ways. The United States paid a high economic price for the war. And it turned U.S. public opinion against involvement there (and subsequently elsewhere - the so-called Vietnam syndrome). Furthermore, the United States lost the war, which strengthened the views of others around the world that U.S. military power was less effective than it had seemed to be-incarnated in the concept of the "paper tiger."

It is in this context that the world-revolution of 1968 took place. It was a world-revolution in the simple sense that it occurred over most of the world, in each of what were at the time considered three separate "worlds." And it was a world-revolution in the remarkable repetitions of two main themes almost everywhere, of course garbed in different local languages.

The first main theme was the rejection of U.S. hegemony ("imperialism") by the revolutionaries, with however an important twist. These revolutionaries equally condemned the "collusion" of the Soviet Union with U.S. imperialism, which was how they interpreted the tacit Yalta accords. In effect, they were rejecting the ideological themes of the Cold War and minimizing the difference between the two so-called superpowers.

The second main theme was the denunciation of the Old Left (that is, Communist and SocialDemocratic parties and the national liberation movements) on the grounds that these movements were not in reality antisystemic but were also collusive with the system.

They pointed to the historic two-step strategy and said that the Old Left movements had in fact achieved the first step — state power-but has not in any serious way changed the world. Economic inequalities were still enormous and growing, internally and internationally. The states were not more democratic, possibly even less so. And class distinctions had not disappeared, merely renamed, the bourgeoisie becoming the Nomenklatura, or some equivalent term. The revolutionaries rejected therefore the Old Left movements as part of the problem, not part of the solution.

While it is true that the revolutionaries were not able to remain in a position of real political strength very long and were suppressed as movements, just like those in 1848, their efforts did have one absolutely major consequence. The world-revolution of 1968 transformed the geoculture. The dominance of centrist liberalism over the two other ideologies came to an end. Centrist liberalism did not disappear; it was simply reduced to being once again only one of three. The radical left and the conservative right re-emerged as fully autonomous actors on the world scene.

What happened next to the movements was largely the consequence of the global economic stagnation of the Kondratieff downturn. The attempts to create new movements of the global leftthe various Maoisms, the so-called New Left Green movements, the neo-insurrectionist 
movements - all turned out to have fleeting support in the face of the economic difficulties that had suddenly become so central to people's lives, again almost everywhere.

Meanwhile, the United States was undertaking a major shift of strategy in order to slow down the rate of its decline. To do this, the United States launched a threefold set of projects. The first had to do with its relation to its erstwhile principal satellites, western Europe and Japan. It offered a new arrangement to the now economically much more powerful and therefore politically more restless regimes. The United States would redefine their role, turning them into "partners" in the geopolitical arena. Institutions were created to implement this new relationship, such as the Trilateral Commission, the G-7, and the World Economic Forum at Davos. The U.S. offer was that the partners might engage in geopolitical moves of which the United States disapproved - for example, West Germany's Ostpolitik, the building of the oil pipeline between the Soviet Union and western Europe, a different policy towards Cuba. The proviso was that this policy independence would be limited and did not go too far.

The second reorientation was the abandonment of the advocacy of developmentalism. In the 1950s and 1960s, everyone (the West, the Soviet bloc, and the Third World) seemed to endorse the concept of national "development"—by which was meant essentially increased urbanization, the growth of an educated stratum, protection of infant industries, and the construction of state institutions and bureaucracies. Suddenly, the global language radically changed. Production for export was to replace protection of infant industries. State enterprises were to be privatized. State expenditures on education and health were to be radically reduced. And above all, capital was to be permitted to flow freely across frontiers. This set of prescriptions received the name of the Washington Consensus, about which Mrs. Thatcher famously proclaimed: "There Is No Alternative" or TINA. The mandate was enforced primarily by the International Monetary Fund (IMF), which refused to give states the loans they badly needed because of the economic downturn unless they agreed to observe these new rules.

The third part of the new strategy was to erect a new world order that ended what is called nuclear proliferation. Essentially, the United States had to accept the reality that the five permanent members of the U.N. Security Council all had nuclear weapons, but they wished the list to stop there. It made this offer to all other counties. A treaty would provide that the five nuclear powers would seek both to the reduce their nuclear weapons and offer aid to the other signatories in the obtaining of nuclear power for peaceful uses to all the rest of the world, provided the others abandoned all pretention to obtaining nuclear weapons. As we know, four countries refused to sign the treatyIsrael, India, Pakistan, and South Africa. But many others acceded and ended their programs.

In fact this threefold redefinition of U.S. strategy, followed essentially by all U.S. presidents from Nixon to Clinton, was partially successful. It did slow down decline without stopping it entirely. The newly-regenerated conservative right, now being called neo-liberals, found this new geopolitical framework very conducive to the rapid growth of their movements. World discourse moved rightwards steadily. Regimes that didn't adjust to this new discourse fell from power. Finally, what had been symbolically defined as the symbol of successful Old Left politics and considered (by both partisans and opponents) to be unchangeable - the Soviet Union-collapsed from within. 


\section{Journal of World-Systems Research}

This collapse was hailed in the Western world as their victory in the Cold War. This interpretation forgot that the whole point of the Cold War had not been to "win" it but to maintain it as a pillar of the world-system. It turned out in fact that the collapse of the Soviet Union would both accelerate the decline of U.S. hegemony and undermine the movements of the neo-liberal right.

The crucial geopolitical event was the first Gulf War (1990-1991), which commenced with the invasion of Kuwait by Saddam Hussein's Iraq. Iraq had for almost a century contested the creation of Kuwait as a separate state by the British. However, it never was in a position to do much about it. During the period in which the Baath party had been in power, the Iraqi regime was supported by the Soviet Union. It had however also been supported by the United States during the 1980 's when the United States encouraged it to engage in the futile war with Iran.

As of 1990, the situation from the Iraqi point of view was dismal. They had paid an enormous price for the destructive war and now owed considerable sums to creditors, one of the largest of which was Kuwait. In addition, they believed Kuwait was appropriating Iraqi oil through slant drilling. But most importantly, the collapse of the Soviet Union, then in process, removed the constraints that Iraq would have felt during the Cold War. It seemed a propitious moment to liquidate Iraqi debts and undo the long-resented "loss" of Kuwait to Iraq.

We know what happened. The United States, after initial hesitation, mobilized the troops necessary to push the Iraqis out of Kuwait. This very action, however, revealed U.S. geopolitical weakness in two ways. First, the United States was unable to bear the costs of its own participation and was subsidized at a $90 \%$ level by four other countries-Kuwait, Saudi Arabia, Germany, and Japan. And secondly, U.S. President George H.W. Bush was faced with the question of whether victorious U.S. troops would proceed to Baghdad or not. He prudently decided that this would be politically and militarily unwise. U.S. action in Iraq thereafter was limited to the imposition of various sanctions. Saddam Hussein remained in power.

Meanwhile, the dismantlement of the Soviet Union and the possibility for all its ex-satellites to pursue independent policies led to a rapid adoption by all of them of neo-liberal policies. However, within a few years, the negative effects of these neo-liberal policies on the real standard of living of the lower strata provoked a reaction wherein erstwhile Communist parties (now renamed) returned to power to pursue a mildly social-democratic program. At the same time, rightist nationalist parties began to gain strength as well. The magic realization of a "Western" style of government with a "Western" level of real economic uplift turned out to be very difficult to realize, and many of these governments became quite unstable.

It is at that point that the antisystemic movements began to revive. The initial reaction to the collapse of the Soviet Union had been an emotional shock and even depression for left movements everywhere, even those that had been long very critical of the Soviet experience. After however a few years of this morose perspective, new light appeared on the horizon for the global left. Some movements refused the sense of inevitability of a triumphal right discourse. There could be a renewed global left discourse.

Thus far, we have been discussing the impact on antisystemic movements of the global stagnation that the Kondratieff B-phase involves. However, there was a further factor, which is the result not of cyclical shifts in the world-economy but of the long-term secular trends. In the ongoing life of historical systems, each cyclical downturn returns not to the previous low point but always to a point somewhat higher. Think of it as two steps upward, one step backward on percentage curves 
that move towards the asymptote of 100 percent. Over the long term, the secular trends must then reach a point where it is difficult to advance further. At this point the system has moved far from equilibrium. We can call this point the beginning of the structural crisis of the historical system.

The short explanation of why historical capitalism has reached its structural crisis is the steady increase over time of the three fundamental costs of production: personnel, inputs, and taxation. Producers make their profits by keeping the total of these costs below the prices at which they are able to sell their products. As these costs rise over time, they reach levels at which the willingness of prospective buyers to purchase the goods is reached, at which point it is no longer possible to accumulate capital via production.

The three costs are each complex, since each is composed of several different subcosts. Personnel costs have always been the one that is most transparent. And among these costs, that of unskilled labor has been the one most discussed. Historically, costs of unskilled labor have risen as workers in Kondratieff A-phases found some way to engage in syndical action. The response of producers in Kondratieff B-phases has been the runaway factory, moving production to areas of "historically lower wages." This curious phrase actually refers to the ability of entrepreneurs to attract laborers from rural areas less tied into the world labor market who would work for lower real wages because these lower real wages offered higher real income than their previous work. After a number of years, these workers became more accustomed to their new environments and learned how to engage in syndical action. At this point, producers would begin to flee to still other areas. This solution for the entrepreneurs depended on the availability of these rural workers. The supply has now begun to be exhausted, as can be measured by the considerable deruralization of the worldsystem today.

The cost of unskilled labor has only been one part of personnel costs. A second part has been the relentlessly increasing costs of intermediate personnel, which were needed both organizationally to meet the complexities of larger corporate structures and politically to serve as a barrier to the syndical demands of unskilled labor.

The solution to increasing costs of unskilled labor has been to eliminate them almost totally from the work force through mechanization. In recent years this has also come to be the solution to increasing costs of intermediate personnel, whose tasks are also being taken over by mechanization. It is actually in the third personnel cost, that of top managers, that the biggest increase in personnel costs has occurred. Those in managerial positions have been able to use their positions as gatekeepers to exact enormous rents, which are extracted from the profits of investors (the shareholders). The bottom line is that today personnel costs are extremely high compared with past costs and constantly increasing.

The story is similar in the cost of inputs. Producers have tried to keep these costs low by externalizing three major types of expenditures: getting rid of toxic waste, renewing raw materials, and building infrastructure. They were able for some 500 years to deal with toxic waste simply by dumping it into public space. But the world has nearly run out of public space, which has led to a worldwide environmentalist movement pressure to clean up the toxicity. This could only be done by the states, which involved the need for higher taxes. It also led the states to seek to force producers to internalize the costs, which has cut into profitability. The exhaustion of public space is analogous to the exhaustion of rural zones largely uninvolved in the market economy. 


\section{Journal of World-Systems Research}

Similarly, the renewal of raw materials was not a problem until the combination of 500 years of usage that was not renewed and an expanded world population led rather suddenly to worldwide acute shortages of energy, water, forestation, and basic foods (fish and meat). The shortages have led in turn to acute political struggles over distribution both within and between countries.

Finally, infrastructure is a crucial element in commercial outlets for production. However, here again producers historically have paid only very partially for their use of the infrastructure, foisting the costs on others, especially the states. Given the ever-rising costs of repairing and extending the infrastructure, the states have found themselves unable to bear the costs, which has led to a serious deterioration worldwide of necessary aids to transport and communications.

Finally, taxes have been steadily rising as well, despite what seems to be constant and enormous tax evasion. First of all, there are multiple kinds of governmental taxes-not only the national taxes that are widely noted but all kinds of local and intermediate structure taxes. These are used, when all is said and done, not merely to pay for the bureaucracy but also to meet the everincreasing demands of the antisystemic movements for educational and health services and the provision of lifetime income guarantees such as pensions and unemployment insurance, which collectively constitute the "welfare state." Despite all the reductions of welfare state provisions that have been forced upon the states, the reality is that these expenditures continue to be significantly larger worldwide than they were in the past.

Nor does governmental taxation exhaust the story. We are daily bombarded with reports of corruption not only in relatively poor countries but even more in relatively rich ones, where there is more money to steal. From the point of view of the entrepreneur, the costs of corruption are every bit as much a tax as those imposed by governments. Finally, the constantly expanding reality of mafiatype operations resulting from the other constraints (especially the shortages) imposes real taxes on the entrepreneur.

As the costs of production have steadily risen (in the pattern of two steps forward, one step backward), the ability to raise the prices of products have been seriously limited by the vastly increased polarization of world income and wealth. Effective demand has fallen as persons have been eliminated from the work force. And as the possibilities of capital accumulation diminish, there has been increasing fear about survival and therefore willingness of both individual consumers and entrepreneurial producers to risk expenditures, which further reduces effective demand. Hence, the world-system arrives at its structural crisis, in which neither the underclasses nor the capitalist entrepreneurs find acceptable returns within the modern world-system. Their attention to turns to the alternatives available.

Once we are into a structural crisis, the system becomes chaotic. That is, the curves begin to fluctuate wildly. The system can no longer function in its traditional manner. It bifurcates, which means two things. One, the system is absolutely certain to go out of existence entirely, but it is intrinsically impossible to know what the successor system or systems will be. One can only outline in general terms what are the two alternative ways in which the chaotic situation can be resolved into a new systemic order.

Two, the bifurcation leads to a great political struggle concerning which of the two alternative possibilities the totality of participants in the system will "choose." That is to say, while we cannot predict the outcome, we can affect it. In terms of the role of the antisystemic movements, the turning-point occurred on Jan. 1, 1995, when the neo-Zapatistas (the EZLN in its Spanish 
initials) rose up in Chiapas and proclaimed the autonomy of the indigenous peoples. Why however on Jan. 1, 1995? Because it was the day on which the North American Free Trade Association (NAFTA) came into operation. By choosing that day, the EZLN was sending the following message to Mexico and the world. The dramatic renewal of the 500-year-old demand of the peoples of Chiapas for self-government was being aimed both at opposing imperialism throughout the world and at Mexico's government for its participation in NAFTA as well as for its oppression of the peoples of Chiapas.

The EZLN emphasized that they had no interest in seizing power in the Mexican state. Quite the contrary! They wished to withdraw from the state and both construct and reconstruct the local ways of life. The EZLN was quite realistic. They realized they were not strong enough militarily to wage a war. Therefore, when sympathetic forces within Mexico pushed for a truce between the Mexican government and the EZLN, they fully agreed. To be sure, the Mexican government has never lived up to the truce agreement, but it has been constrained in how far it could go because of the support the EZLN was able to muster.

This support was the result of the second major theme the EZLN pursued. It asserted its own support for all movements of every kind everywhere that were in pursuit of greater democracy and equality. And the EZLN convened so-called intergalactic encounters in Chiapas to which they invited the entire global left. The EZLN also refused sectarian exclusions in these meetings - the pattern of the Old Left. They preached instead inclusiveness and mutual tolerance among the movements of the global left.

The revival of the global left received its second strong reinforcement in 1999. One of the principal objectives of the global right had been to institutionalize the Washington Consensus by adopting within the framework of the World Trade Organization (WTO) a treaty that guaranteed what were called intellectual property rights in all signatory countries. This would have effectively barred these countries from producing their own less expensive products for their own use and for sale to other countries - for example, in pharmaceuticals.

There were two remarkable aspects to Seattle. First of all, there was a major protest movement surrounding the meeting, which was composed of three forces that had hitherto never joined forces: the labor movement (and specifically the AFL-CIO), environmentalists, and anarchists. In addition, the members of these groups who were present were largely U.S. persons, giving the lie to the argument that only in the Global South could one mobilize opposition to neo-liberalism.

The second remarkable aspect is that the protests succeeded. They enabled some sympathetic delegations within the WTO meeting to hold out against adopting the new treaty. The WTO meeting disbursed without a treaty. It was a failure. And ever since, any attempt to adopt the treaty has been blocked. The WTO became irrelevant. Furthermore, the Seattle protests led to widespread copying of the protest technique at international meetings of all kinds, to the point that conveners of such meetings began to schedule them for remote locations where they had a better possibility of blocking the presence and size of such protest movements.

This then brings us to the third major development in the second wind of antisystemic movements - after Chiapas and Seattle came Porto Alegre and the World Social Forum (WSF) of 2001. The initial call for the 2001 meeting was a joint effort of a network of seven Brazilian organizations (many of left Catholic inspiration but also the principal trade-union) and the ATTAC movement in France. They chose the name of World Social Forum in opposition to the World 


\section{Journal of World-Systems Research}

Economic Forum (WEF) that had been meeting at Davos for some 30 years and was a major locus of mutual discussion and planning of the world's elites. They decided to meet at the same time as the Davos meetings to emphasize the contrast and they chose Porto Alegre as the site of the 2001 meeting to underline the political importance of the Global South.

The organizers made the crucial decision that the meeting was open to all those who were against imperialism and neo-liberalism. They also made the more controversial decision of excluding political parties and insurrectionary movements. Finally, they decided not to have officers, elections, or resolutions. This was in order to frame a "horizontalist" approach to organizing the world's antisystemic forces, as opposed to the "verticalist" and therefore exclusionary approach of the Old Left movements. To summarize all this, they chose as the motto of the meeting the now famous slogan, "Another world is possible."

Porto Alegre was unexpectedly a major success. The conveners had hoped to attract 5000 people and they attracted 10,000. To be sure, the initial participants were heavily from Brazil and close-by countries and from France and Italy. But they immediately did two things. They decided to continue with the Porto Alegre meetings, seeking to expand the participation geographically. And they created an international council, more or less by co-option, to oversee the organization of future meetings. In the years that followed, the WSF met in different parts of the Global South and with an enormous increase of the number of participants. In this sense, it has been a continuing success.

However as the first decade of the twenty-first century went by, the dilemmas of the WSF came to the fore. They can best be understood in the context of the evolution of the world-system itself. There were two major elements in this evolution. The first was the bubble crisis in the U.S. housing market in 2007-2008, which led commentators around the world to recognize the existence of some kind of "crisis" in the world-system. The second was the economic and geopolitical rise of the "emerging" economies - in particular but not only the so-called BRICS (or Brazil, Russia, India, China, and South Africa).

Together, the two issues led to a public debate about the enormous wealth gap and about the future of the geopolitical dominance of the Global North - and to great uncertainty among commentators about how to assess these events. Were we to think of it as fundamental change or as a passing bump on the world-economic and geopolitical scene? The antisystemic movements and their partisans have been equally ambivalent about how to assess the debate about inequality and the rise of the "emerging" nations. It has also led to an acute debate within the WSF about its successes and failures.

The antisystemic movements now face a number of serious dilemmas. The first is whether or not to recognize the existence of a structural crisis of historical capitalism. The second is about what should be the priorities of their short-term and middle-term activities. The most noticeable thing about antisystemic movements in the second decade of the twenty-first century is the degree to which the debates that embroiled them in the last third of the twentieth century, once exorcised in the world-revolution of 1968, have returned to plague them, virtually unchanged.

There were three debates that we outlined earlier. The first concerned the role of the states in the achievement of a different kind of historical system. The second was that between social movements and nationalist movements about the leading historical actor in the struggle for a more just historical order. The third was between the verticalists who insisted that multiple oppressed groups had to subordinate their demands to the priorities of the principal historical actor and the 
horizontalists who insisted that the demands of all oppressed groups were equally important and equally urgent, and should not be deferred.

Well, here we are again! Inside the WSF and in the larger global justice movement, there are those who shun in every way state power and those who insist that obtaining state power is an essential prerequisite. There are those who insist on the priority of the class struggle (1\% vs. 99\%) and those who insist on the priority of the nationalist struggle (South vs. North). And there are those who are verticalist, insisting on joint political action whether within the WSF or the wider global justice movement, and those who are horizontalist, insisting on not neglecting the truly forgotten groups, the lowest global strata.

These debates have been most visible in Latin America because it has become a prime locus of global developments on all these fronts most vividly. For various reasons (including the decline of U.S. geopolitical power), there have come to power in the twenty-first century a large number of governments that are on the left or at least left of center. There has also been a movement, led in different ways both by Venezuela and by Brazil, to create South American and Latin American structures (UNASUR and CELAC) that excluded the United States and Canada. There have also been steps towards creating regional economic zones and structures (Mercosur, Bancosur).

At the same time, these governments of the left, center-left, and of course the few on the political right) have all pursued developmentalist policies, which involve extractive policies that violate the traditional zones of indigenous peoples. These latter groups have accused the left governments of being as bad in this respect as their rightwing predecessors. The left governments in turn have accused the indigenous movements of acting objectively and deliberately in accord with rightwing internal groups and the United States geopolitically.

The net result is a divided Global Left in the political struggle over the new systemic order it is trying to build by tilting the bifurcation in the direction of a relatively democratic, relatively egalitarian world-system (or world-systems). Of course, the Global Right is also engaged in an internal debate about tactics, but that is of little comfort to the Global Left.

One way to analyze the options for the Global Left is to put them in a time frame that distinguishes short-term priorities and middle-term priorities. All of us live in the short-term. We need to feed ourselves, house ourselves, sustain our health, and just survive. No movement can hope to attract support if it doesn't recognize this urgent need for everyone. It follows, in my view, that all movements must do everything they can to alleviate immediate distress. I call this action to "minimize the pain." This requires all sorts of short-term compromises, but it is essential. At the same time, one must be very clear that minimizing the pain in no way transforms the system. This was the classic social-democratic illusion. It merely minimizes the pain.

In the middle-run (that is, the next 20-40 years), the debate is fundamental and total. There is no compromise. One side or the other will win. I call this the battle between the spirit of Davos and the spirit of Porto Alegre. The spirit of Davos calls for a new non-capitalist system that retains its worst features - hierarchy, exploitation, and polarization. They could well install a world-system that is worse than our present one. The spirit of Porto Alegre seeks a system that is relatively democratic and relatively egalitarian. I say "relatively" because a totally flat world will never exist, but we can do much, much better than we have done heretofore. There is, in this sense, possible progress.

We do not know who will win in this struggle. What we do know is that, in a chaotic world, every nano-action at every nano-moment on every nano-issue affects the outcome. That is why I 
continue to end discussion of these issues with the metaphor of the butterfly. We learned in the last half-century that every fluttering of a butterfly's wings changes the world climate. In this transition to a new world order, we are all little butterflies and therefore the chances of tilting the bifurcation in our direction depends on us. The odds are fifty-fifty. It follows that our efforts as activists are not merely useful; they are the essential element in our struggle for a better world. 